\section{公民館の避難所転用に関わる要 件}

一船橋市におけるケーススタディー

\section{MATTERS TO AFFECT REFUGE CONVERSION OF KOHMINKAN} -The case study of Funabashi-shi-

\author{
浅野平八—*1 広田直行— $* 2$ \\ キーワード： \\ 公民館, 災害対策, 避難所, 施設内オープンスペース率, 学習諸室率, 支援拠 \\ 点 \\ Keywords : \\ KOHMINKAN, Measures against disasters, Refuge, Inner open-space rate, \\ Learning room rate, Support foothold
}

Heihachi ASANO $-* 1 \quad$ Naoyuki HIROTA $-* 2$

In this report, the condition to utilize citizen's hole, which is referred to as KOHMINKAN in Japan, as primary shelter in disaster is studied. The case studies for the KOHMINKAN in Funabashi-shi, Chiba prefecture are performed. The rate of learning room and the rate of open space are utilized as the analysis parameters to identify the conditions of shelter. As the result, it is clarified for the taking capacity of refuge people when the KOHMINKAN is utilized as shelter and the condition to utilize the facilities as the base for disaster support activites.

\section{1. はじめに}

公民館が災害時に近隣住民の避難場所となることは、希ではない。 しかし1995年の阪神淡路大震災のように、被災 1 週間後に神戸市内 だけで 22 万人超えて避難所での生活を余儀なくされた例は希であ る。この災害では、約 $60 \%$ の人が学校施設を避難所としており、こ の他に公民館・公会堂等の公共施設、社宅や駐車場等の民間施設も 使用された。このような避難所と避難生活についての実態調查は建 築学会建築計画委員会のもとで行われ、筆者もWGの一員として参 加した ${ }^{* 1}$ 。そして大地震の警告が出され続けている関東地方におけ る災害時の避難状況を想像して、前掲の調查では報告されていない 公民館等の施設について、避難場所としての可能性を検証する必要 を感じた。市町村内で小学校についで施設量の多い公共建築が公民 館であるが、「災害時すぐに公民館」という状況に如何に対応する かという課題について阪神淡路の状況をふまえると共に、筆者が継 続調査している千葉県船橋市の公民館をケーススタディとして、公 民館の避難所転用に関わる要件についてまとめたのが本報告である。

阪神淡路の震災での避難場所について共通することは、まずその 場所が破壊されてなく安全であるという確認作業がなされ安堵の気 持ちを持った後、そこに集まった人達によって緊急救援活動の拠点 として発動しはじめるということがある。そして救援活動が迅速に 行われた場所には、それなりの地域活動が日常的になされていた。 つまり、安全な構造物と普段の地域活動が、被災直後の避難場所 （以下一次避難場所と記す）が形成される条件であったと考えらる。 筆者のヒヤリング調査“2でも、情報や救援物資の供給拠点として
の小学校と、被災者が生活する場所としての近隣公共施設という機 能分担が徐々になされ、一次避難、二次避難と続いた避難世帯の転 居先は仮設住宅へと移ったことが確認された。広域大災害では長期 にわたる対策が必要なわけである。そこで災害時での公共施設の利 用計画を再整備するためにも、日常的に地域住民の活動の場となっ ている公民館の避難所としての可能性と限界を検討しておく必要が あると考える。

\section{2. ケーススタティの方法}

公民館が避難場所として使われるには、維持されるべき耐震安全 性や環境水準、対象となる防災圈域や圏域内の防災街路、住民の日 頃の関心をあつめ帰属意識を生む事業、災害に対応する住民組織な どの問題が存在する。しかし最も重要なことは、公民館として日常 的に利用されている施設空間が、災害時にいかに対応できるかとい う理解を、施設管理者や周辺住民が普段から持つことだと考える。

災害時に避難場所として開放できる施設内空間の特定の方法につ いては、筆者の既往研究で示した公共建築の室空間分析の方法に関 する指標を適用した。一つは「施設内オープンスペース率（１ＯS 率）」で、「施設の建築延べ床面積」に対する「施設内の自由利用 可能なスペースの合計面積」の割合を示す指標である*3。

今ひとつの指標は「学習諸室率」で、「施設の建築延べ床面積」 に対する「学習活動に使用される室の合計面積」の割合でる*4。

これらの指標の数値計算の過程で、自由利用スペースや学習活動 に使用可能な室の特定が重要となる。この特定作業をもとに、本来

\footnotetext{
${ }^{* 1}$ Prof., Dept. of Architecture and Architectural Engineering, College of Industrial Technology, Nihon Univ., Dr. Eng.

*2 Research Assoc., Dept. of Architecture and Architectural Engineering, College of Industrial Technology, Nihon Univ., M. Eng.
}

(干275-8575 習志野市泉町1-2-1) 
の目的と異なった避難所転用の可能性を検討する。またこれらの指 標をもとに、公民館を避難所として使用した場合の収容可能人数を 試算する。

\section{3. 調查対重施設の骤要}

船橋市公民館は1949年社会教育法制定時より設置が始まった。草 創期は牛小屋や小学校の転用で始まり、近年は多種の地域施設と複 合してコミュニティの拠点施設として位置づけられている。1983年、 市基本計画で市内が23のコミュニティに分割され、公民館設置の対 象圈域となっている。地域活動をすべて吸収することができる中心 的地域施設という位置づけである。いくつかの市町村にみられるよ うな各種施設の乱立競合がここにはみられず、地域的拠点の形成過 程が公民館の発達の過程であることが特徴である*5。

表-1 調查対象事例一覧（1997年現在）

\begin{tabular}{|c|c|c|c|c|c|c|}
\hline No. & 施設名称 & 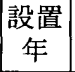 & \begin{tabular}{|c} 
竣工 \\
年
\end{tabular} & $\begin{array}{c}\text { 敷地 } \\
\mathrm{m}^{2}\end{array}$ & $\begin{array}{c}\text { 延床 } \\
\mathrm{m}^{2}\end{array}$ & 併設施設 \\
\hline 1 & 西 & S 25 & S 44 & 1,553 & 1,527 & \\
\hline 2 & & S 24 & S 45 & 1,033 & 714 & \\
\hline 3 & 三 & S 50 & $|\mathrm{~S} 50|$ & - & 853 & 中学校 \\
\hline 4 & 東 & S 28 & S 52 & 809 & 1,513 & 消防署 \\
\hline 5 & & S 29 & S 52 & 4,243 & 980 & 出張所 \\
\hline 6 & 海老が作 & S 54 & $\mathrm{~S} 54$ & 2,440 & 999 & 中学校 \\
\hline 7 & 高 根 & S 55 & S 55 & 1,169 & 1,032 & \\
\hline 8 & 習志野台 & $\mid \mathrm{S} 56$ & S 56 & 2,432 & 1,089 & 図書館 \\
\hline 9 & 夏 見 & S 56 & $|\mathrm{~S} 56|$ & 1,158 & 920 & \\
\hline 10 & 浜 & S56 & $\mid \mathrm{S} 56$ & 1,035 & 2,063 & \\
\hline 11 & & $\mid \mathrm{S} 56$ & S 56 & 1,241 & 761 & 児童ホーム・連絡所 \\
\hline 12 & 八木が谷| & S 58 & S 58 & 2,344 & 1,027 & 児童ホーム \\
\hline 13 & 飯 山 満 & S 59 & S 59 & 1,029 & 1,032 & \\
\hline 14 & & 560 & $S 60$ & 1,369 & 1,031 & \\
\hline 15 & & S61 & S 61 & 2,076 & 1,199 & 児童ホームム \\
\hline 16 & & $|\mathrm{~S} 63|$ & S 63 & 3,009 & 1,643 & \\
\hline 17 & 咲\| & H 1 & $\mathrm{H} 1$ & 3,279 & 1,291 & 児童ホーム \\
\hline 18 & 新 高 根| & H 2 & H 2 & 2,635 & 1,405 & 児童ホーム・老人憩の家 \\
\hline 19 & & H 2 & H 2 & - & 1,299 & （6 階建ての 2 階部分） \\
\hline 20 & 薬 円 台 & H 3 & H 3 & 1,826 & 1,567 & 児童ホームム・老人梸の家 \\
\hline 21 & 二 和 & S 49 & H 3 & 4,057 & 1,805 & 出張所・図書館 \\
\hline 22 & 松 が丘 & H 5 & H 5 & 1,813 & 1,564 & \\
\hline 23 & 高 根 台而 & H 8 & H 8 & 1,553 & 1,527 & 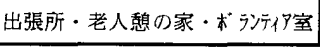 \\
\hline
\end{tabular}

※設置年は機関としての創設年，竣工年は現在の建物の竣工年を示す.

\section{4.設置目的からみた避踓宿泊可能な空问の特定}

阪神淡路大震災では一時避難の缩泊場所として、施設内の空き居 室はもとより、ロビー・廊下等が使われた。災害時における避難所 としては、施設内空間の使用の可能性と居住環境に関わる条件が問 題となる。ここではまず使用可能なスペースとして、施設内オープ ンスペース（inner open space 略して IOS と記す. IOS の抽出方 法については文献 3 を参照されたい）をみる。船橋市全公民館の実 態調査から各施設ごとに最大值を求めて、その建築延床面積に対す る割合、すなわち最大 I O S 率を求めたのが図ー2である。ここで 各施設 80〜 60\%の範囲が開放可能であることがわかる。

つぎに災害時の避難宿泊が可能な空間について設置目的別に吟味 考察すると以下のようである。

[事務管理］を目的とする空間では 1 事例で相談室の設置があり、 可動家具の撤去により使用が可能となる。
[集団活動]を目的とする空間は全て避難宿泊可能である。しか し、全施設に設置された室合計66事例中、机や椅子などの収秋スペ 一スを備えた室は13室にすぎず、可動家具の収納場所の確保が問題 となる。また、床仕上げがコンクリート防塺処理のみであるため、 長期間の滞在には不適な例が 1 事例ある。

[技術習得]を目的とする音楽室が 9 室中 7 室まで収納庫を備え ている。さらに前室で八キ力工を行う事例もあり、衛生的にも有効 な空間である。実習室は全て料理実習のためのもので、調理台や食 器棚等の固定家具による占有率が高く、避難宿泊としては不適であ る。しかし、この空間は災害時の支援活動において、避難者の食事 や炊き出し場所となる可能性のある空間である。

[個人利用] を目的とする図書室や図書コーナー・資料室がある。 これらの空間では書架の設置位置とその占有面積が問題となる。ま た、学習机・椅子などの可動家具についても収納場所がなく、避難 宿泊には難しい空間もある。

[多目的利用]を目的にした空間は最も避難宿泊所転用に有効な 空間といえる。和室は就寝にも適し、押入も備えている。講堂や体 育レクレーション室は大空間であるため多人数の収容が可能である が、個人のプライバシー確保は難しい。また、講堂では自然採光の ない長期滞在に不適な場所もある。

[交流］を目的とする空間では家具の撤去と、玄関付近の設置が 多いことによる床材衛生面での問題がある。また当然歩行空間が交 差するところでは避難宿泊に不適となる。

[共同利用］の空間では 1 事例で地下駐車場を有しており、季節 にもよるが、雨風がしのげるという点で一次的に利用可能な矤間と いえる。便所や湯沸室は避難宿泊者の生活必需空間である。

災害時の一次避難宿泊が可能な空間（表ー2のアミカケで示した 空間）の面積が延床面積に占める割合を求めると図ー 3 にあるよう に、各施設 $80 \sim 60 \%$ の範囲で可能である。これは図-2 の最大 I O $\mathrm{S}$ 率と近似するが内容は異なる。すなわち表一 2 にあるように、I O S 外の室も含まれている。また、I O S に含まれる共同利用スペ 一スの一部が不適であることによる。

このように避難所として転用可能な公民館の室空間は、設置目的 で分類すると表－20ようであるが、それぞれに環境条件は異なり 緊急避難の場所として対応可能ではあるが居住性については問題が 多い。

表 -2 室名称の設置目的による分類

\begin{tabular}{|c|c|c|c|c|c|c|}
\hline \multicolumn{3}{|c|}{ I O S 外 } & \multicolumn{4}{|c|}{ I OS } \\
\hline 事務管理 & 集団活動 & 技術習得 & 個人利用 & 多目的利用 & 交 & 共同利用 \\
\hline 事務室 & 小会㯰 & 実習室 & 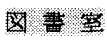 & 講 堂 & DE $\mathbb{E}-$ & 風 除 室 \\
\hline 耝 腅 & 集 会耋| & 親僡賞案 & 図書aー- & 体有し力屋 & 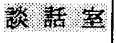 & 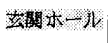 \\
\hline 館 長室 & & 意楽室 & 料 至 & 和 案 & 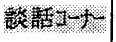 & 解 \\
\hline 機 械 室| & & & & & フウンジ| & 階 段 室 \\
\hline 倉 庫 & & & & & 木ール & 便 所 \\
\hline 潐 備 室| & & & & & 小? 1 I & 湯 沸 窒 \\
\hline & & & & & & ロッカー室 \\
\hline & & & & & & 駐車場 \\
\hline
\end{tabular}

（寨習室は全て調理可，体育レク室は体育レクレーション室の略） 凡例 : 避難宿泊可能な室 


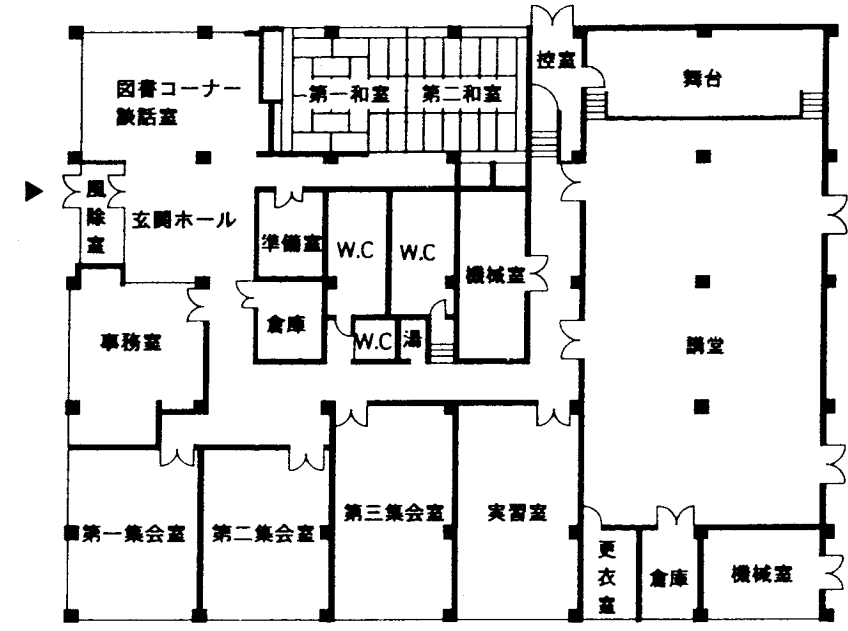

図-1 船橋市公民館の室構成事例（№.6 海老が作公民館·平屋）

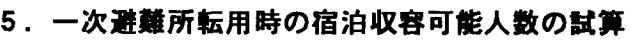

阪神淡路大震災において、兵庫区役所の避難者数がピークとなっ

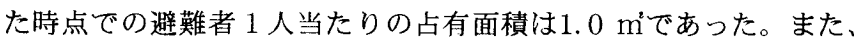
須磨区内の小学校でもスペースと避難人数との関係から、ピーク時 は約 $1 \mathrm{~m} /$ 人前後であったと推測されている*。。しかしこれらの数 值は、人間の生理的環境保持を無視する値であり、最低限横になれ るスペースとして畳 1 帖（約 $1.6 \mathrm{~m}^{2} ）$ は必要と考える。そこで本報 告では、一次避難においての避難者 1 人当たりの占有面積基準を、 $1.6 \mathrm{~m}^{2} /$ 人として試算すると、船橋市公民館においては一次避難所 として 350 人 / 館 800 人 / 館、 23 事例合計で 12,200 人の収容が可能 となる。

\section{6. 支援活動と二次通離所}

阪神淡路大震災の例からも、公民館には支援活動拠点としての役 割が大きくなる。また平成 9 年に行われた「公民館の災害対策に関

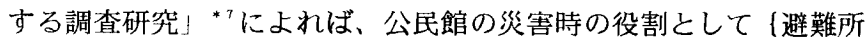
・救援物資の保管配給場所・ボランティア活動の拠点・情報提供の ためのセンター\} などの機能が上げられている。このような支援活 動拠点としての機能を果たす際には、小室群、すなわち前揭表－2 の集団学習・技術習得・個人利用の学習諸室が有効である。船橋市 公民館の学習諸室の面積が延床面積に占める割合は図－4のように、 40\%〜20\%の範囲にあり、支援活動のための会議や事務処理、連絡 拠点のスペースとして転用可能な状態にある。

そこで公民館を避難所に転用した場合の役割を、既存の室構成に 応じて、一次避難と二次避難に分けて設定してみると表 -3 のよう になる。

二次避難時において、避難者 1 人当たりの占有面積には、德返り できる必要面積として $2.3 \mathrm{~m}^{2 * 8}$ 、和室の収容人員の算定基淮として 1 人当たりの面積基準に $2.5 \mathrm{~m}^{2} \sim 3.2 \mathrm{~m}^{2 * 9}$ 、青年の家の和室宿泊定 員 1 人当たりの面積基準として $2.5 \mathrm{~m} 〜 2.8 \mathrm{~m}^{2 * 10 、 な と ゙ か ゙ あ る 。 ~}$

そこで公民館が二次避難の場所となった場合の避難宿泊可能者数 を、 $2.5 \mathrm{~m}^{2} / 人 と し て$ 算出した。ここで収容数は公民館の二次避難 宿泊可能数を示すが、当然これは小学校区の人口を下回るものであ るから、大災害の際には長期的対応のためにも、公民館には一次避 難所としてより二次避難所としての役割を求めるべきと考える。
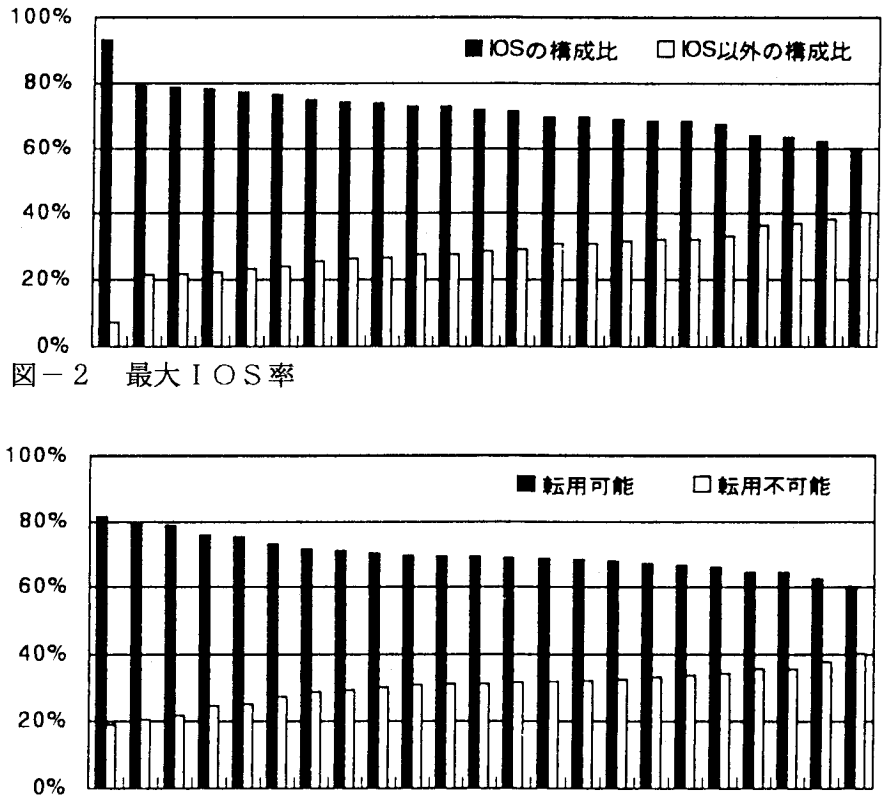

図-3 一次避難場所として転用可能な延床面積比率

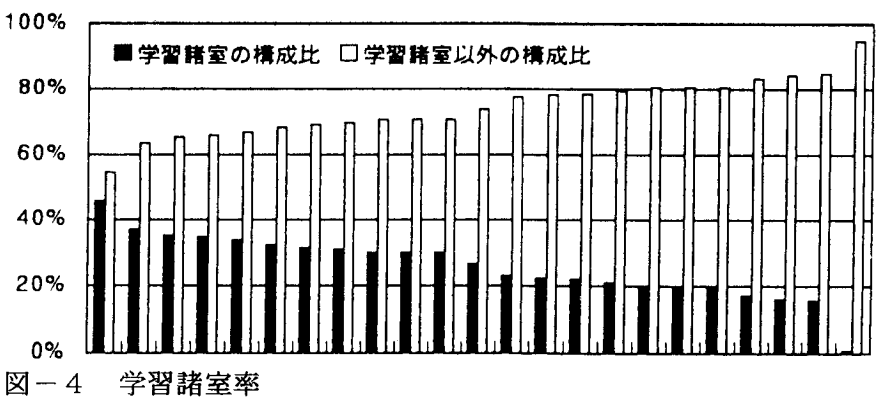

表 -3 公民館の避難所転用時の室用途構成

\begin{tabular}{|c|c|c|}
\hline \multicolumn{3}{|c|}{ 一次避難所としての公民館の役割 } \\
\hline & 機能項目 & 使用可能な室名称 \\
\hline $\begin{array}{l}\text { 避 } \\
\text { 難 } \\
\text { 宿 } \\
\text { 泊 }\end{array}$ & $\begin{array}{l}\text { - 宿泊 } \\
\\
\text { - 炊事 } \\
\text { - 洗面 } \\
\text { - 排泄 } \\
\text { - 入浴 }\end{array}$ & 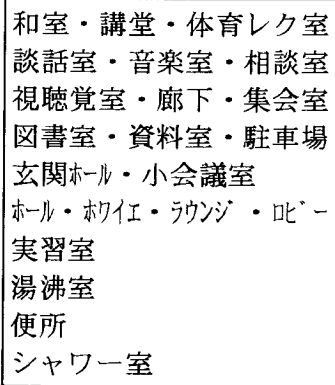 \\
\hline \multicolumn{3}{|c|}{ 二次避難所としての公民館の役割 } \\
\hline & 機能項目 & 使用可能な室名称 \\
\hline $\begin{array}{l}\text { 避 } \\
\text { 難 } \\
\text { 宿 } \\
\text { 泊 }\end{array}$ & $\begin{array}{l}\text { - 宿泊 } \\
\text { - 炊事 } \\
\text { - 洗面 } \\
\text { - 排泄 } \\
\text { - 入浴 }\end{array}$ & $\begin{array}{l}\text { 和室・講堂・体育レク室 } \\
\text { 談話室・相談室 } \\
\text { 実習室 } \\
\text { 湯沸室 } \\
\text { 便所 } \\
\text { シャワ一室 } \\
\end{array}$ \\
\hline $\begin{array}{l}\text { 支 } \\
\text { 援 } \\
\text { 活 } \\
\text { 動 }\end{array}$ & $\begin{array}{l}\text { ・炊き出し } \\
\text { ・ ボランティア等の宿泊 } \\
\text { ・救援物資の保管 } \\
\text { ・仮診療所 } \\
\text { ・ ボランティア活動のセンター } \\
\text { ・情報提供のセンター }\end{array}$ & $\begin{array}{l}\text { 䒠習室 } \\
\text { 音楽室 or 視聴覚室等 } \\
\text { 集会室 or 小会議室等 } \\
\text { 集会室 or 小会議室等 } \\
\text { 集会室 or 小会議室等 } \\
\text { 事務室・ロビー・廊下等 }\end{array}$ \\
\hline
\end{tabular}


全公民館で 3,339人の二次避難宿泊が可能ということになる。

避難所生活の長期化に伴い、プライバシーの確保や自然採光・換 気などを含めた居住性がさらに求められる。このため二次避難所と しての空間は、動線が集中する玄関ホールや廊下・無空の講堂など は不適格である。施設が災害時に避難場所となるには、まず日常か らその施設が地域的拠点として成り立っているかが大きく関わる。 このため施設の在り方としてオープン化が求められる。しかし災害 時の避難宿泊利用に扮いては、オープン化がプライバシ一確保の点 からはマイナスに作用することになる。各施設の空間構成を考虑し た災害時の役割分担が必要と考える。公民館にあっては、炊事や入 浴が可能なことから、二次避難宿泊としての役割も可能である。

\section{7. 対魚圆域と収宫可能人数}

各公民館の対象圈域にある小学校区（一時避難場所）と対応して みたのが表ー 4 である。

公民館圈域と小学校区の関係は整合性がもたれるように整備され てきており、4 割の公民館が小学校と隣接している。また、この他 の事例も、市の避難場所指定となっている中学校・広場・公園・競 馬場・神社などと近接し、これらを含めると公民館の 8 割が災害時 に有効な外部環境を有していることになる。つまり公民館を災害時 における支援活動の拠点として位置づけ、小学校や公園等のスペー スと連携した避難計画をたてることで有効な対応が成されると考え る。

表 -4 公民館の二次避難缩泊可能数と小学校区の関㐿

\begin{tabular}{|c|c|c|c|c|c|}
\hline 公民館区 & 小学校区 & 収容数 & 公民館区 & 小学校区 & 収容数 \\
\hline 部 & 小栗原 & 187 & & 八木が谷北 & \\
\hline 典 & 法 典 & 97 & & 咲が丘 & \\
\hline & 法典西 & & 飯 山 満 & |飯山満 & 112 \\
\hline 田 & $\equiv$ 山 & 181 & & 飯山满南 & \\
\hline & $\begin{array}{l}\text { 三山東 } \\
\text { 田喜野井 }\end{array}$ & & 丸 山 & \begin{tabular}{|lr} 
法典東 \\
$丸$ & 山
\end{tabular} & 131 \\
\hline 部 & $\begin{array}{l}\text { 前 原 } \\
\text { 中野木 } \\
\text { 二 宮 }\end{array}$ & 129 & 塚 田 & $\begin{array}{l}\text { 嫣田 } \\
\text { 行田西 } \\
\text { 行田東 }\end{array}$ & 125 \\
\hline 北 部 & $\begin{array}{ll}\text { 豊 } & \text { 富 } \\
\text { 坪 } & \text { 井 }\end{array}$ & 119 & 宮 本 & \begin{tabular}{|ll} 
宮 & 本 \\
峰 & 台
\end{tabular} & 214 \\
\hline 海老が作 & $\begin{array}{l}\text { 大 穴 } \\
\text { 大穴北 }\end{array}$ & 149 & 三 咲 & 市 場 & 133 \\
\hline 根 & $\begin{array}{ll}\text { 高 } & \text { 根 } \\
\text { 金 } & \text { 杉 } \\
\text { 金杉台 }\end{array}$ & 128 & 新 高 根 & $\begin{array}{l}\text { 票根東 } \\
\text { 芝山西 } \\
\text { 芝山東 }\end{array}$ & 122 \\
\hline 習志野台 & $\begin{array}{l}\text { 高 郷 } \\
\text { 習志野台第一 } \\
\text { 習志野台第二 }\end{array}$ & 137 & \begin{tabular}{lrr|} 
葛 & 飾 \\
薬 & 円 & 台
\end{tabular} & \begin{tabular}{|l} 
葛 飾 \\
薬円台 \\
薬円台南
\end{tabular} & $\begin{array}{l}145 \\
160\end{array}$ \\
\hline 見 & $\begin{array}{l}\text { 八 栄 } \\
\text { 夏見台 }\end{array}$ & 127 & 二 和 & $\begin{array}{ll}\text { 七 } & \text { 林 } \\
\text { 三 } & \text { 咲 }\end{array}$ & 205 \\
\hline 浜 & 南本町 & 325 & & 二 和 & \\
\hline & 若 松 & & 松が芹 & 古和釜 & 140 \\
\hline & 湊 町 & & 高 根 台\| & 高根台第一 & 128 \\
\hline 室 & 小 室 & 17 & & 高根台第二 & \\
\hline 八木が谷 & 八木が谷 & 128 & & 高根合第= & \\
\hline ? & ほ瞵接 & & 収容可䏍 & 能人数 合計 & 3,339 \\
\hline
\end{tabular}

\section{8. 避斯所転用に淮わる要件}

公民館が避難所として使われるについては、まず避難者の居場所 があること、つぎに設置条例や災害救助法などのもとで避難場所と して制度化されていること、住民が公民館への求心性と利便性を意 識していること、各種地域施設のなかで公民館が拠点化しているこ となどの要件が整っていることがケーススタディの結果としてみら れた。

また、建筑計画の視点から整理してみると以下のようである。（） は特に二次避難所としての要件を示す。

()施錠の有無

○施設内オープンスペースの動線と出入口の位置 ○隣接施設との機能連携および複合

・床仕上げ材の影響

・八キ力工線の位置と下足処理

・固定家具の占有面積と避難宿泊可能面積の関係

・可動家具の収納庫および移動場所

・講堂や体育館などへの自然探光

\section{(まとめ)}

一次避難場所・二次避難場所となった場合の公民館の収容数算出 方法、支援活動拠点となつた場合の空間利用の可能性と役割につい て報告した。

ケーススタディとして示した船橋市のように、各コミュニティに 拠点施設が網羅されている場合は、各施設の収容数を考慮しての一 次・二次避難場所指定とともに、拠点施設職員の災害救助支援を想 定した訓練が必要と考える。

注

*1 柏原士郎・上野浮・森田孝夫編著：阪神・淡路大震災における避難所 の研究, 大阪大学出版会, 1998年 1 月

*2 調查期間 : 1995 年5 7 月 : 避難所の状況調查 1996年 2月：地域福祉センタ一実態調查 1996年 3 月 : 公園亡避難所の複合形態

*3 著者の以下の日本建築学会計画系論文集による 「公共建筑のオープン化に関する基嘫的研究 $1 」 490$ 号，pp. 83〜 92

$\begin{array}{lll}\text { 同 } & 2 & 503 \text { 号, } \\ \text { 同 } & 3 & 512 \text { 号, } 101 \sim 108\end{array}$

*4 淺野平八他: 生涯学習関連施設の学習諸室, 日本建箖学会地域施設計 画研究 $12, p p .113 \sim 118 ， 1994$ 年 7 月

* 5 浅野平八：地域集会施設の計画と設計，理工学社，pp. 176 179, 1995年

*6*1文献

*7 文部省委託調查：「公民館の災害対策に関する調查報告書」，社全国 公民館連合会, 1997年

＊8 日本建築学会編：建築設計資料集成 3 ，丸善，pp. 65，1980年 生命工学工業技術研究所編：設計のための人体寸法デー夕集, 人間生 活工学研究センター，1996年

* 9 服部扶桑 : 計画要素之平面，彰国社，pp. 95，1975年

*10 河野通祐・浅野平八: 青年の家・少年自然の家, 井上書院, 1975年 